\title{
Novel Traditions of Library as Societal Culture Conservation
}

\author{
Wiji Suwarno \\ Institut Agama Islam Negeri (IAIN) Salatiga \\ wiji.suwarno@gmail.com
}

\begin{abstract}
Library is not only a space for displaying books, but there are many important values within. The paradigm of library has been shifted from books oriented into user oriented meaning library is as sources of information. Besides that, library plays its roles as an institution of cultural heritage conservators in maintaining cultural values, and revitalizing the tradition. In this technology era, this article tries to explain the interesting phenomena in the libraries of the State Institute for Islamic Studies (PTKIN) in Indonesia concerning the history of the emergence and development of such novel traditions including Online Research Skill (ORS) and Writing Skill (RS).
\end{abstract}

Keywords: $\quad$ Novel Culture, online research skill, writing skill.

\section{Introduction}

Library as the center of knowledge is an institution that dedicates all resources to organize information related to library itself and other field of studies in structuring nation characters and knowledge. The reason is that library provides many opportunities for users to explore information within. Furthermore, the information can be modified to create new knowledge. Unfortunately, library from the perspective of Indonesian society is perceived as an intuition for merely compiling books. They still have negative memory and experience about such perspective of library. 
That phenomena is contradictory with Ranganathan statement in the previous decades. His complete name is Shiyali Ramamrita Ranganathan (1892-1972). As the father of Indian library science, he develops the ideal concept of library service. In his concept, he has mentioned the five laws of library. This concept is also well known to date and becomes the reference for recent studies. Those rules are also replicated as the principals of library philosophy.

1. Books are for use.

2. Every reader his or her book.

3. Every book its reader.

4. Save the time of the reader .

5. The Library is a growing organism. ${ }^{1}$

Human thoughts are evolving along with the world development. When computer becomes icon of technology development, and the internet is the hero for networking in modern era, Gorman rises with a new idea that discussing past condition of library with today library on the basis of information technology. In this case, Gorman explains an opinion about library on five items which are acknowledged as Gorman's laws. He interprets Ranganathan law according to current contexts. The following list is his arguments:

1. Libraries serve humanity

2. Respect all forms by which knowledge is communicated.

3. Use technology intelligently to enhance service

4. Protect free access to knowledge; and

5. Honor the past and create the future ${ }^{2}$

Gorman views the dynamic side of library that wisely discusses based on current development. The element of culture becomes the nuance of library as a technical unit. It is blended with the role of technology to support side by side in managing archive documents to create future culture. The question

\footnotetext{
${ }^{1}$ Alireza Noruzi, “Application of Ranganathan's Laws to the Web," Webology 1, no. 2 (2004): 2, http://eprints.rclis.org/handle/10760/7252.

${ }^{2}$ G.E Gorman and Peter Clayton, Qualitative Research For The Information Proffessional: A Practical Handbook, 2nd ed. (London: Facet Publishing, 2005).
} 
is what the culture is.

In this context, culture is inseparable with thinking process during the routine of work flow in library. From that process, the idea on the roles of library related to the development of information and technology emerges.

\section{The Roles of Library}

In this era, information is attached together with the development. The development itself is resembled with the existence of technology. In other words, technology plays as the container, or it is the tool. Meanwhile information is the content. Library is an institution that organizes information in the archive format. That format can be perceived as history and becomes references to create future.

Floridi argues that history is actually recorded past time information. Due to history, people are full of wisdom, and they can think intelligently. The change of how people think is due to how they interpret past time events. Thus, history can be included as part of culture. No records no history, so history is actually synonimous with the information age, since prehistory is that age in human development that precedes availability of recording systems. ${ }^{3}$

Included in giving services to users, librarian have to make user to be happiness. According to Gordon statement, at least there are three elements creating principals of librarians, which are made librarians have excelent services skill.

1. Listening. Librarian need to pay attention to, and learn from,staff, peers, customers, and administration. As Kari Baumann, Branch Manager, Centennial Park Branch Library, Greeley, Colorado, says: "I think the most important thing any new manager can do is to listen to her staff, and to library staff that she doesn't supervise to understand the organization as a whole."

2. Assertiveness and self-confidence. Many new library managers have difficulty transitioning, not only into dealing with staff as a manager rather

${ }^{3}$ Luciano Floridi, Information: A Very Short Introduction (Oxford, 1995), 3. 
than as a peer, but into dealing with their own bosses and colleagues in a self confident and effective manner. Take charge from the beginning.

3. A willingness to be proactive. Why wait for problems to pile up or for complaints to find you? Look for ways to improve library service, working conditions for staff, workflow, or funding, and then act on achieving your goals in these areas.

4. Communication. realize here the importance of maintaining open and frequent communication with anyone you supervise or report to.

5. Lifelong learning. No library manager can afford to stagnate in her position. ${ }^{4}$

Those five roles are the main responsibilities of library in managing information. They are actually the culture of library that is inseparable and requires development. The development can be exemplified in the academic library in the University of Technology that plays its roles in academic fields in terms of creating and disseminating scientific information. Since the scientific publication in Africa is left behind, academicians are disgrace and motivated to write more scientific publication in local journals. Their attitude affects the revolution of local publication and improve their institution promotion values when the journals are accessed globally as credible references for researches. ${ }^{5}$ Such development role becomes the inspiration for the writer to overview the current developing culture in the library of the State Institutes for Islamic Studies (PTKIN) Indonesia.

\section{The Roles of Library as The Culture Conservator}

Library plays its roles as the culture conservator. It means that library organizes many fields of knowledge. In fact, knowledge is the result of thinking culture, the culture of scientific conduct, the culture of integrating 2004), 19.

${ }^{4}$ Rachel Singer Gordon, The Accidental Library Manager (Medford, N.J: Information Today,

${ }^{5}$ Elisha R.T. Chiware, "Positioning the Technological University Library in Higher Education and Human Resources Development in Africa," Library Management 31, no. 6 (July 27, 2010): 397, doi:10.1108/01435121011066153. 
experience. The term of culture in this paper extends into civilization. In terms of civilization, it is perceived as the development of human thought in the form of historical artefacts and documents. Thus, it can be concluded that library has a role in conserving culture because it is the place to storage information as the result of human thoughts in archived information.

The shift from analog to digital world forces library to adapt and accept any adjustment. It is also indispensable to avoid internet as the icon of development in this digital era.

The existence of internet has promote great optimism on the ease and access speed toward information. On the contrary, internet also creates extraordinary pessimism toward the existence of library because the limitation of librarian to chase the development of such information technology.

Since the emergence of internet, the thinking culture alters. Internet users in the world reaches 3.175 billions, and Indonesia is in the six rank of the world internet users with 88,1 million users in 2014. From that number, most users own and occupy social network application. They are around $87,4 \%$, and the rest apply conventional technology. ${ }^{6}$

The statistic data show the interest of internet users and the types of purposes. It means that unintentionally the need for information is also sky rocketing neglected the information content.

\section{Library as The Media of Culture Conservation}

Book is one form of culture. Civilization is often measured from the number of detected intellectual documentation. The empire of Rome is well known for develop civilization because scientists exist and infrastructures are symbolized in the artefacts of buildings and books in libraries. The library of Alexandria is the evidence of Rome civilization as it collects more than 600 hundred books at that time. This is the symbol that civilization has evolved since the past.

\footnotetext{
${ }^{6}$ Nuning Kurniasih, "Kualifikasi Pustakawan Di Era Digital," in Prosiding Semiloka Kepustakawanan Indonesia 2015 (Jakarta: FPPTI, 2015), 439.
} 
Starting from the early development of library, collection oriented becomes the prior purpose of library. The growing number of collection becomes the characters of library quality. In the digital era the condition has changed. The library orientation moves from books oriented into user oriented. It means that library provides services for the needs of users, and library becomes the source of information. In short, the users can visit library to access information and respectively produce new information based on their references.

As library has an important role in conserving culture, it mainly contributes as in the following:

1. Compiling literature including books and non-books as the source of information

2. Managing and maintaining literature

3. Providing services on literature.

In general, library holds several functions: 1) Information function, library provides various type of information in the format of printed materials, recordings, or other collections to fulfil the needs of school members; 2) Educational function, library becomes an institution to improve educational quality and implement the purpose of education; 3) Cultural function, library is a structure to develop life quality and promote reading culture; 4) Recreation function, library is a space to spend pastime with reading for pleasure; 5) Research function, library is complete with collection to support research activities; 6) Deposit function, library is responsible to storage and conserve masterpiece including printed or no-printed materials published in Indonesia. Further, library can intensively play its roles in conserving culture by significantly providing local books, and if possible, it should be published by local libraries in certain provinces by spending state budget. The books may cover:

a. Publishing books on local potentials.

b. Publishing books on local culture.

c. Managing cultural documents in digital format 
The alternative strategy in conserving culture is by transforming media from conventional collections into digital ones. It is dispensable that this era is in the line with previous civilization. This digital era is symbolized with the variety of media and date in the digital format. Library grasps this development by managing digital information. The information can be derived from conventional format or any formerly digital one. We should bear in mind that technology development has changed the method of how to serve people and the practical attitude in the field of library and information. ${ }^{7}$

The evolution of societal culture is synchronous with the pattern of people thought. The result can be in the format of values, attitude, and also artifacts. Fortunately, they can be found in library. In this case, library manage knowledge, cultural values, ultimate service as representation of attitude format. Book, in this context, resembles the format of artifacts. There are two important roles of library in conserving culture namely:

1. Revitalizing cultural values. The most important thing in conserving nation culture is preserving the noble values of local culture as the guidance of people attitude and behavior in social cultural live. Cultural conservation which mainly emphasizes on properties and artefacts will not deliver significant impact toward Indonesian development. Indonesia requires identity and characters as a nation, and it can be done by developing awareness based on the history and culture.

2. Revitalizing lost tradition. Translation and adaptation of old manuscripts from original languages into local ones, so they are readable by modern society. This efforts have been done by experts nationally and internationally. Their contribution is immense especially in revitalizing the triumph of the past. The old time becomes an important aspect in human life because it works as the source of inspiration and the mile stone for future leaps. The library contribution in the effort of revitalizing the triumph of the past can be clearly seen in the exhibition of ancient pre-Christian literature using old Latin language by Humanist society.

${ }^{7}$ Alan Brine, ed., Handbook of Library Training Practice and Development. Volume Three (Farnham, Surrey; Burlington, VT: Ashgate, 2009), 10. 


\section{Novel Tradition of The Libraries in PTKIN}

Cultural heritage is a history story about artifacts, architectures, texts, and something intangible such as language, folklore (literature) as part of culture. ${ }^{8}$ Library is an institution that organizes those items in the format of scientific collection such as books, journals, magazines, and other documents. They are managed and presented for the sake of users' needs including cultural collection.

Cultural collection has important meaning because 1) The informasi can be used to indicate the elements that develop a group or a nation culture; 2) As the source of knowledge, culture is the form of creative activities, intention, and human feeling, so the technique and knowledge form those activities can be utilized and developed; 3) As the source of wisdom and moral values, culture consists of teaching about how to deal with people, how to interpret birth, marriage, mortality, and how to connect with nature; 4) As it has economic and tourism values, the form of culture presents in the deceptive shapes with the elements of esthetic and uniqueness, so they can be displayed. Culture which is invitingly exhibited and packed can be watched, appreciated, even it can yield profits. Besides that, culture can be a tool to introduce a nation or certain local culture. ${ }^{9}$

If the context of culture conservation relates to knowledge, the library of PTKIN Indonesia holds two novel traditions that have been developing namely:

1. Online Resource Skill, the skills of searching documents or information that are organized online. In the cultural context, such information can be in the format of documents or manuscripts that have been transformed into digital documents.

2. Writing skill, the skills in writing and creating novel information in the format of scientific writing. Writing works as a media in expressing ideas

${ }^{8}$ Janet Stevenson, Dictionary of Information and Library Management. (London: A. \& C. Black, 2006), 49, http://www.credoreference.com/book/acbinfomanage.2006

${ }^{9}$ Farid Rahmat Saleh, "Perpustakaan Sebagai Pusat Kebudayaan," UIN Yogyakarta, 2009, 2, http://digilib.uin-suka.ac.id/4124/1/BAB\%20I,V,\%20DAFTAR\%20PUSTAKA.pdf. 
and knowledge to public. In terms of cultural conservation, it means as the activities of documenting or recording or archiving societal culture. For example, if people have local stories or folklores, they can be saved in a written formats, so any people can read them until the next generation.

Those two activities can be perceived as novel traditions in conserving culture in society. Based on that statement and also librarian responsibilities, librarian has important roles in conserving nation culture. Therefore, it can support the development of local culture into Indonesian one. According to the Ministry of Information and Technology Indonesia, Indonesian culture is the variety of Indonesian local culture including cultural arts, dances, songs, local housing structures, local outfits, local ceremonies, the beauty of landscape, animals, and potential natural resources and strategic areas. If those cultural elements are arranged in the format of books, librarian should have responsibility to inform library users and to advertise the books. Thus, people will comprehend their local, national, or even international culture.

\section{Closure}

It can be concluded that library is not merely a space to store books and for exhibition. There are many important values within. The paradigm about library has shifted from books oriented into user oriented, from solely book arrangement on the shelf into the source of information. The novel culture achieved from library activities in the context of culture conservation includes online resource skills and writing skills. Those skills play important roles in storing and presenting documents in the digital format, and also recording and archiving societal culture which is intangible into written manuscripts.

\section{Bibliography}

Brine, Alan, ed. Handbook of Library Training Practice and Development. Volume Three. Farnham, Surrey; Burlington, VT: Ashgate, 2009.

Elisha R.T. Chiware. "Positioning the Technological University Library in Higher Education and Human Resources Development in 
Africa." Library Management 31, no. 6 (July 27, 2010): 391-403. doi:10.1108/01435121011066153.

Floridi, Luciano. Information: A Very Short Introduction. Oxford, 1995.

Gordon, Rachel Singer. The Accidental Library Manager. Medford, N.J: Information Today, 2004.

Gorman, G.E, and Peter Clayton. Qualitative Research For The Information Proffessional: A Practical Handbook. 2nd ed. London: Facet Publishing, 2005.

Kurniasih, Nuning. "Kualifikasi Pustakawan di Era Digital." In Prosiding Semiloka Kepustakawanan Indonesia 2015, 439-50. Jakarta: FPPTI, 2015.

Noruzi, Alireza. “Application of Ranganathan's Laws to the Web." Webology 1, no. 2 (2004). http://eprints.rclis.org/handle/10760/7252.

Saleh, Farid Rahmat. "Perpustakaan Sebagai Pusat Kebudayaan.” UIN Yogyakarta, 2009. http://digilib.uin-suka.ac.id/4124/1/BAB\%20 I,V,\%20DAFTAR\%20PUSTAKA.pdf.

Stevenson, Janet. Dictionary of Information and Library Management. London: A. \& C. Black, 2006. http://www.credoreference.com/book/ acbinfomanage. 